\title{
Polymer and protein surface coatings on silicone: effect on Staphylococcus epidermidis adhesion and colonization KY Simon $\mathrm{Ng}^{* 1}$, Haiying Tang ${ }^{1}$, Ting CaO ${ }^{1}$, Anfeng Wang ${ }^{1}$, Xuemei Liang ${ }^{1}$, Steven O Salley ${ }^{1}$ and James P McAllister II ${ }^{2}$
}

Address: ${ }^{1}$ Department of Chemical Engineering and Materials Science, Wayne State University, 5050 Anthony Wayne Drive, Detroit, MI 48202 USA and 2Department of Pediatric Neurosurgery, Children's Hospital of Michigan and Wayne State University, 4201 Antoine Street, UHC-6E, Detroit, MI 48201, USA

Email: KY Simon $\mathrm{Ng}^{*}$ - sng@wayne.edu

* Corresponding author

from 50th Annual Meeting of the Society for Research into Hydrocephalus and Spina Bifida

Cambridge, UK. 30 August - 2 September 2006

Published: 21 December 2006

Cerebrospinal Fluid Research 2006, 3(SuppI I):S4I doi:I0.II86/I743-8454-3-SI-S4 I

(c) $2006 \mathrm{Ng}$ et al; licensee BioMed Central Ltd.

\section{Background}

Surface modifications of silicone have been attempted to reduce the incidence of shunt infections. However, the influence of surface hydrophobicity, roughness, and functional groups on bacterial adhesion has not been fully elucidated, and reports of protein effects are conflicting. Therefore, we have tested silicone coated with different biopolymers, silanes, and proteins to determine how these modifications influence Staphylococcus epidermidis adhesion and colonization.

\section{Materials and methods}

Silicone was coated with heparin, hyaluronan, octadecyltrichlorosilane (OTS), and perfluorodecyltrichlorosilane (FAS). Proteins, including bovine serum albumin (BSA), human serum albumin (HSA), $\gamma$-globulin, and fibrinogen were immobilized on the surface of silane-modified silicone. Comparisons were also made with physically adsorbed protein on silicone. The quality and stability of these coatings were examined by contact angle measurement, X-ray photoelectron spectroscopy, and atomic force microscopy. A colony-counting adhesion assay and scanning electron microscopy (SEM) were used to quantify bacterial adhesion and colonization.

\section{Results}

The contact angles of FAS, OTS, heparin, and hyaluronan coating on silicone were $112.2^{\circ}, 102.3^{\circ}, 55.3^{\circ}$, and $55.3^{\circ}$, respectively, and these coatings were stable for 30 days. After a $4 \mathrm{hr}$ incubation with $\mathrm{S}$. epidermidis, the pattern of least to greatest colony counts was: FAS - OTS hyaluronan - silicone - heparin. After a $12 \mathrm{hr}$ incubation, the size and number of colonies increased significantly, hyaluronan/OTS/silicone and heparin/OTS/silicone showed the least and greatest degree of bacterial adhesion, respectively. Immobilized protein on modified silicone surfaces was stable in saline for 30 days, while physically adsorbed protein showed instability within hours. The amount of nitrogen on all types of immobilized proteins was similar, but less on physically adsorbed protein. All protein immobilized on OTS/silicone surfaces significantly reduced bacterial adhesion by around 75\% compared to untreated silicone, while physically adsorbed BSA on silicone reduced adhesion by only $30 \%$.

\section{Conclusion}

While surface hydrophobicity and roughness did not appear to be determining factors on overall bacterial adhesion, the nature of surface functional group had a significant influence on the initial adhesion and subsequent colonization processes. FAS-coated silicone surfaces displayed the greatest inhibition of bacterial adhesion and 
colony formation. Protein covalently immobilized on OTS/silicone reduced bacterial adhesion and colonization, with BSA having a greater effect than physically adsorbed BSA. However, different types of protein inhibited bacterial adhesion to a similar extent, possibly due to a comparable surface concentration of $-\mathrm{NH}_{2}$ groups. These findings are helpful for devising novel strategies to reduce shunt infections.

Publish with Bio Med Central and every scientist can read your work free of charge

"BioMed Central will be the most significant development for disseminating the results of biomedical research in our lifetime. " Sir Paul Nurse, Cancer Research UK

Your research papers will be:

- available free of charge to the entire biomedical community

- peer reviewed and published immediately upon acceptance

- cited in PubMed and archived on PubMed Central

- yours - you keep the copyright

Submit your manuscript here:

http://www.biomedcentral.com/info/publishing_adv.asp 